\title{
PANDEMIC WITH COVID-19 AND FAMILIES WITH CHILDREN WITH CHRONIC RESPIRATORY DISEASES
}

\author{
Tatjana Zorcec $^{1}$, Tatjana Jakovska ${ }^{2}$, Vesna Micevska ${ }^{1}$, \\ Katerina Boskovska ${ }^{2}$, Valentina Cvejoska Cholakovska ${ }^{1}$ \\ ${ }^{1}$ University Children's Hospital, Skopje, RN Macedonia \\ ${ }^{2}$ Institute for Respiratory Diseases in Children, Skopje, RN Macedonia
}

Corresponding author: Tatjana Zorcec, University Children's Hospital, Skopje, RN Macedonia, e-mail: tzorcec@ gmail.com

\section{ABSTRACT}

COVID-19 pandemic has provoked a huge change in daily functioning in millions of people worldwide. The epidemiological measures in prevention of possible infection have increased the possible risks on the mental and physical health.

We have conducted a survey in order to investigate the needs and challenges of families with children with chronic respiratory diseases. In this order, we have created a questionnaire with general information about the family, general information about the child with chronic respiratory disease, overall physical and mental health before and during the pandemic, needs and mental health condition of the parents/caregivers.

This survey showed that this group of families of children with respiratory disorders have suffered financially in significant way and has changed the way they perform professional and educational patterns due to the pandemic. Most of the children were stable in their physical health, but their mental health has deteriorated. This is probably due to the regular contact with the medical staff, but not with the mental health professionals. This group of children has a significant reduction in their physical activity and increase the hours in front of TV screens. The further effect on the physical and mental health is to be investigated.

Keywords: COVID-19 pandemic, chronic respiratory disease, children

\section{INTRODUCTION}

Originally identified in Wuhan, China, in December 2019, the novel corona virus, known as Severe Acute Respiratory Syndrome Corona Virus 2 (SARS-CoV-2), has become a global pandemic [1-3]. Up till now, more than 11 million cases have been reported worldwide, with more than 500.000 deaths due to its related disease, Corona Virus Disease 2019 (COVID-19) [4]. In North Macedonia, as of July 2020 the outbreak had reached 7.000 reported cases and more than 300 deaths.

COVID-19 presents with respiratory symptoms, from mild to severe, and a significant percentage of patients develop Acute Respiratory Disease Syndrome (ARDS). These severe symptoms are associated with a true cytokine storm, in particular IL-6, and death can be one of the outcomes [5]. 
Although the number of children affected by the disease is small, and most of them show mild symptoms, the containment measures probably intend to have negative impact on the mental and overall health and well-being of children as well as their families. The current situation affects children, adolescents and their families in an exceptional way. Kindergartens and schools have been closed, social contacts strongly limited and out-of-home leisure time activities canceled. Parents are asked to support their children with home schooling, while at the same time working from home. For typical psychological development and wellbeing of children, companionship and social interaction is an essential component. Furthermore, there is an increased risk of developing psychiatric disorders, whenever there is separation of children from their caregivers $[6,7]$. According to recent studies, children who were quarantined at facilities or centers, might be more susceptible to mental health problems than children who were quarantined at home because of their higher risk of infection and fear caused by parental separation $[8$, 9]. Children who are (or suspected to be) infected with COVID-19 and need isolation or quarantine might require special attention to meet their fear, anxiety and other psychological effects [9].

Most of the countries in the world, due to COVID-19 pandemic, have a re-organization of hospital services. There have been closures, partial closures or reduced services of inpatient and daycare facilities, with outpatient contacts reduced in some places to emergency cases only [10]. In children, allergy and asthma are among the most prevalent non-communicable chronic diseases, and healthcare providers taking care of these patients need guidance. There is no evidence that currently available asthma and allergy treatments, including antihistamines, corticosteroids, and bronchodilators, increase the risk of severe disease from COVID-19. [11].

Changes in healthcare availability have important implications on chronic conditions that require ongoing medical attention. School cancellations mean that children no longer have exposure to viruses that can cause asthma exacerbation. Staying at home limits children's opportunities for physical activity, known to be beneficial in asthma. It is unclear whether underlying conditions such as asthma place children at greater risk for disease. But, even in households with infected adults where children do not contract COVID-19, there may be heightened emotional distress that may worsen the child's asthma symptoms [12]. Tuberculosis (TB) is also one of the many areas in the global public health that will be sidelined and adversely affected by the COVID-19 pandemic. As most TB in young children is acquired in their own household, social distancing measures that keep a family together for long periods of time are likely to result in more exposure of children to infectious TB index cases [13].

Management of Cystic Fibrosis (CF) patients requires complex, time-consuming treatment with frequent hospital visits, and there is a strong probability that COVID-19 pandemic may cause anxiety among children with $\mathrm{CF}$ and their families. According to a recent study from Turkey, there was a moderate, positive correlation between the state anxiety scores of the mothers and trait anxiety scores of the 9-12 year-old children. Also, providing information about COVID-19 to parents of children with CF by their own doctors may have a positive effect on families, especially those with younger children and with chronic Pseudomonas infection [14].

A very crucial, but apparently overlooked issue is the psychological impact of COVID-19 outbreak on all children and adolescents. Both young and older children are likely to become more demanding, having to cope up with all of the changes, and may exhibit impatience, annoyance and hostility, which in turn may cause them suffering from physical and mental violence by the parents. The interaction between their daily-routine changes, home confinement, and fear of infection could further intensify these undesirable mental reactions resulting in a vicious cycle [15].

\section{AIM OF THE STUDY}

To screen some of the challenges and needs of the families of children with chronic respiratory diseases in the Republic of Macedonia, during the pandemic with COVID-19.

\section{METHODOLOGY}

For this survey, we have created a questionnaire, with 118 questions related to the following domains: general information about the family, general information about the child with chronic respiratory disease, overall physical and mental health before and during the pandemic, needs and mental health condition of the parents/caregivers. The survey was conducted during May, June and 
the first week of July, 2020. It was anonymous and voluntarily. The subjects were recruited from a group of parents of children with chronic respiratory diseases, who are receiving services at both institutions and those who respond on the public call for participation. In total, we have a group of 72 parents/caregivers. In the group we have parents/caregivers of children with Cystic Fibrosis (CF), Asthma, Tuberculosis (TB) and Rhinitis Allergica. We have conducted descriptive analyses and t-test with Statistica 7 program.

\section{RESULTS}

In this section we present the most significant results acquired from the survey.

Table 1. Family demographic characteristics

\begin{tabular}{|l|c|}
\hline Characteristic & $N(\%)$ \\
\hline Subjects & $72(100 \%)$ \\
\hline Child'age & $7.3 \pm 2.89$ \\
\hline Relationship to child & \\
\hline Mother & $63(87.5 \%)$ \\
\hline Father & $9(12.5 \%)$ \\
\hline Other & $0(0 \%)$ \\
\hline Highest level of education & $3(4.2 \%)$ \\
\hline Primary school & $33(45.8 \%)$ \\
\hline Secondary school & $30(41.7 \%)$ \\
\hline University degree & $6(8.3 \%)$ \\
\hline Higher than college & $3(4.2 \%)$ \\
\hline Spouse's highestlevel of education & $32(44.4 \%)$ \\
\hline Primary school & $31(43.1 \%)$ \\
\hline Secondary school & $6(8.3 \%)$ \\
\hline Some college / university & $59(81.9 \%)$ \\
\hline Higher than college & $13(18.1 \%)$ \\
\hline Households & $36(50 \%)$ \\
\hline City & $36(50 \%)$ \\
\hline Country & $66(91.7 \%)$ \\
\hline House & $2(2.8 \%)$ \\
\hline Flat & $4(5.5 \%)$ \\
\hline Family constellation & $\mathbf{2 . 0 9 \pm 0 . 7 7}$ \\
\hline Married & \\
\hline Single parent & \\
\hline Other & Average number of chiddren in the \\
household &
\end{tabular}

Graph 1. Employment status during the COVID-19 pandemic (first graph mainly mothers, second graph mainly fathers)

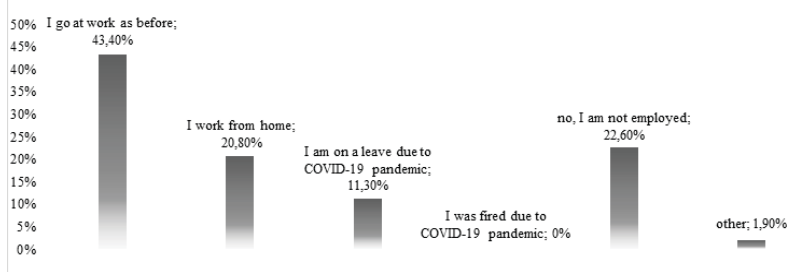

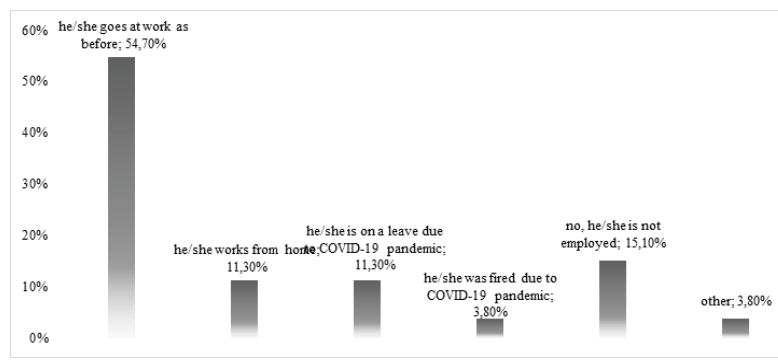

Pie 1. Financial difficulties due to COVID-19 pandemic

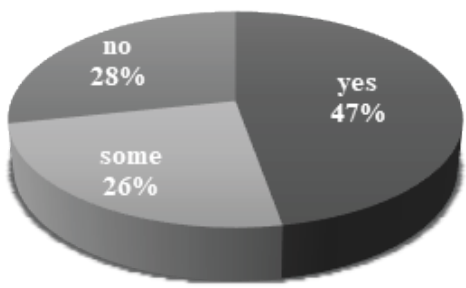

Table 2. Medications before and during the pandemic

\begin{tabular}{|l|c|}
\hline Characteristic & $N(\%)$ \\
\hline Subjects & $72(100 \%)$ \\
\hline Use of medication before pandemic & \\
\hline Yes & $79.2 \%$ \\
\hline No & $20.8 \%$ \\
\hline $\begin{array}{l}\text { Modification in medications during } \\
\text { the pandemic }\end{array}$ & \\
\hline No & $67.9 \%$ \\
\hline Yes & $30.2 \%$ \\
\hline Other & $1.9 \%$ \\
\hline
\end{tabular}

Table 3. Checkups during the pandemic

\begin{tabular}{|l|c|}
\hline Characteristic & $N(\%)$ \\
\hline Subjects & $72(100 \%)$ \\
\hline $\begin{array}{l}\text { Regular checkups during the } \\
\text { pandemic } \\
\text { Yes }\end{array}$ & $62.3 \%$ \\
\hline No & $37.7 \%$ \\
\hline $\begin{array}{l}\text { Difficulties in connecting with the } \\
\text { medical staff }\end{array}$ & $7.5 \%$ \\
\hline Yes & $92.5 \%$ \\
\hline No & $30.3 \%$ \\
\hline $\begin{array}{l}\text { No regular checkups-reasons } \\
\text { Institution is not available due to } \\
\text { pandemic }\end{array}$ & $30.7 \%$ \\
\hline Fear of virus exposure & $37.1 \%$ \\
\hline No need, stable health condition & $1.9 \%$ \\
\hline Other & \\
\hline
\end{tabular}


Graph 2. Mental health of the children before and during pandemic

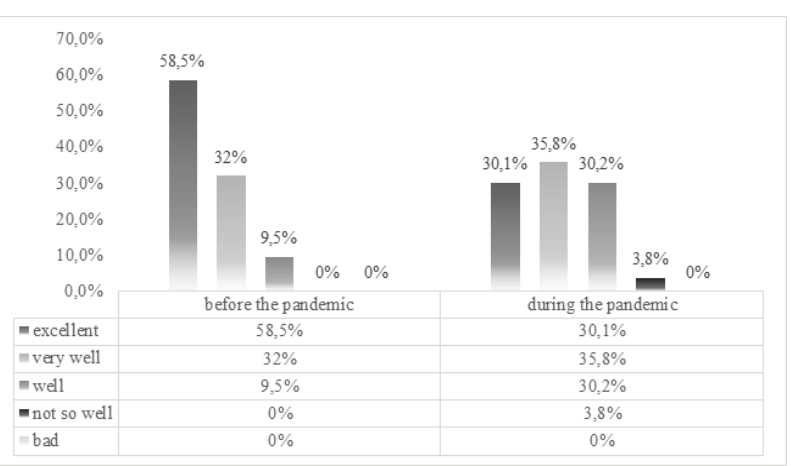

We have calculated t-test between the two proportions $(58.5 \%$ and $30.1 \%)$ for children who were feeling very well before and during the pandemic and the difference is statistically significant ( $\mathrm{p}=0.0006)$, as well as for the two proportions $(9.5 \%$ and $30.2 \%)$ for feeling well $(\mathrm{p}=0.0019)$. This means that statistically significant number of children deteriorated in their mental health from very well to well.

Graph 3. Physical health of the children before and during pandemic

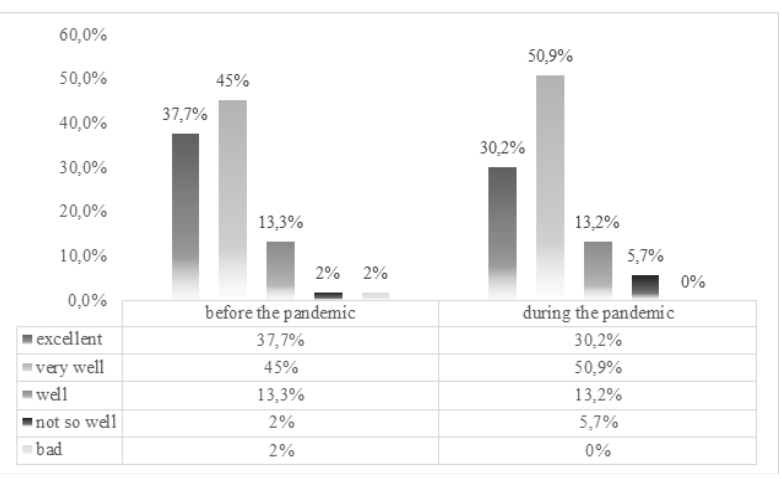

Graph 4. Physical activity one month before and during the pandemic

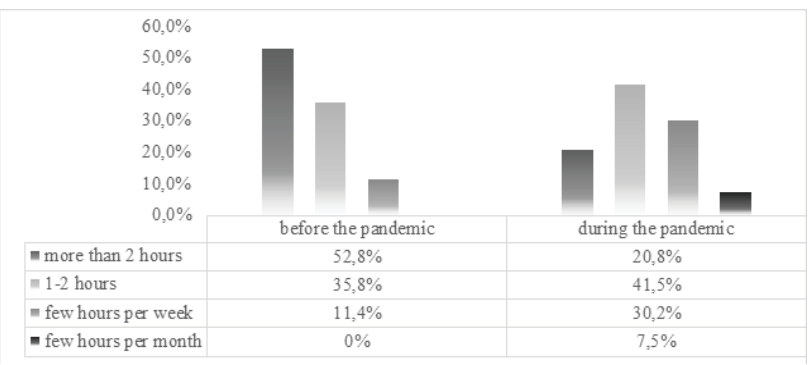

We have calculated the t-test between the two proportions $(52.8 \%$ and $20.8 \%)$ for children who were spending more than 2 hours of physical activity before and during the pandemic and the difference is statistically significant $(\mathrm{p}=0.0001)$, as well as for the two proportions $(11.4 \%$ and $30.2 \%)$ for few hours per week $(\mathrm{p}=0.0056)$. This means that statistically significant number of children deteriorated in their physical activity from more than 2 hours per day to few hours per week.

Table 3. Children's routines during the pandemic

\begin{tabular}{|c|c|c|c|c|c|}
\hline & & $\frac{\frac{0}{0}}{\sigma}$ & 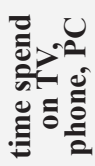 & & 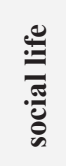 \\
\hline worsen & 13.2 & 24.5 & 52.9 & 34 & 37.7 \\
\hline the same & 64.16 & 60.2 & 33.9 & 58.5 & 56.6 \\
\hline improved & 22.64 & 15.3 & 13.2 & 7.5 & 5.7 \\
\hline
\end{tabular}

Among the most frequent behavioral problems, parents stated: getting in arguments with the siblings $(64.15 \%)$ and with the parent $(38.3 \%)$ more often than before the pandemic. Parents reported feeling of fatigue much more during the pandemic (53.5\%) and very high level of self-contentment $(73.5 \%)$ for finishing all the needed activities during the day like schooling, house works, shopping the necessities, work related activities.

\section{DISCUSSION}

In response to control the COVID-19 pandemic, drastic changes and stressful conditions were introduced, including lockdowns, school closures, quarantines, travel restrictions, social distancing, transformation in professional and educational patterns, and alteration in the typical lifestyle of millions people worldwide $[8,16]$. In our country, those measures have also been implemented. Stressors such as prolonged duration of the pandemic, fear of infection, frustration, inadequate information, lack of in-person contact with classmates, friends, and teachers, lack of personal space at home, and family financial loss can have even more problematic and enduring effects on children and adolescents [17]. Even more, there are concerns regarding the potential negative impact on the physical and mental health 
especially in younger children. The stress levels in children quarantined with family members might be eased to some degree, compared with children who are separated from their caregivers, including children infected with or suspected of being infected with SARS-CoV-2, who are quarantined in local hospitals, and children whose caregivers are infected with SARS-CoV-2 or who have died from the disease. $[8,9]$

Changes in healthcare availability, have important implications on chronic conditions who require ongoing medical attention, like chronic respiratory diseases, for example. Many medical practices all around the world, including primary care and pulmonology practices, have limited office visits to urgent patient needs and have largely moved to telehealth visit formats. $[12,13,14]$ In our study, a statistically significant number of children deteriorated in their mental health from condition of very well to well, but not in physical health, before and during the COVID-19 pandemic. This is probably due to the doctor's availability for consultations. During the pandemic, in $62.3 \%$ of the cases, they had regular onsite checkups, $92.5 \%$ had been in regular contact with the medical staff and only $7.5 \%$ had difficulties in connecting with their doctors. The impact on long-term access to medical providers, as the COVID-19 pandemic continues, remains unknown and needs careful monitoring, as well as condition with the mental health. This findings also suggest that in this stressful condition due to the pandemic, children with chronic diseases need to have regular checkups with mental health professionals, too. Furthermore, they need to keep up with daily routines as far as possible, or make new healthy ones [16]. COVID-19 also has impact on medication prescriptions. Parents of children with respiratory chronic disease may have heightened concerns about disease control during a respiratory illness pandemic, potentially increasing medication adherence in their children $[12,19]$. Our results suggest that medical doctors didn't need to modify the therapy received before the pandemic and most of the children were clinically stable.

The negative effects on health during the outbreak can be much more worsen when children are isolated and confined to their homes without physical activities and interaction with their peers. In our study, statistically significant number of children deteriorated in their physical activity from more than 2 hours per day to few hours per week. Evidence suggests that when children are out of school, during the weekends and holidays, they are physically less active, have much longer screen time with their phones, $\mathrm{PC}$, in front of $\mathrm{TV}$, spending their time most sedentary, going to bed later and sleeping letter. They are usually on less favorable diets, which together with reduced physical activity result in weight gain $[8,20,21]$. Rundle et al. also anticipated that the COVID-19 pandemic will likely double out-of-school time this year for many children and will increase the risk factors for weight gain, usually associated with summer vacation [22].

\section{CONCLUSIONS}

COVID-19 pandemic has provoked a huge change in daily functioning in millions of people worldwide. Epidemiological measures in prevention of possible infection has increased the possible risks on the mental and physical health. This survey showed that this group of families of children with chronic respiratory disorders have suffered financially in significant way and has changed the way they perform professional and educational patterns due to the pandemic. Most of the children were stable in their physical health, but their mental health has deteriorated. This is probably due to the regular contact with the medical staff, but not with the mental health professionals. This group of children has a significant reduction in their physical activity and increase the hours in front of TV screens. The further effect on the physical and mental health is to be investigated.

\section{REFERENCES}

1. Huang C, Wang Y, Li X, et al. Clinical features of patients infected with 2019 novel coronavirus in Wuhan, China. Lancet 2020; 395: 497-506.

2. Zhu N, Zhang D, Wang W, et al. A novel coronavirus from patients with pneumonia in China, 2019. N Engl J Med 2020; 382: 727-33

3. Guan WJ, Ni ZY, Hu Y, et al. Clinical characteristics of coronavirus disease 2019 in China. N Engl J Med 2020; 382: 1708-20. 
4. World Health Organization. Coronavirus disease (COVID-19) pandemic. Available at: https:// www.who.int/docs/default-source/coronaviruse/ situation-reports, Accessed July 6, 2020.

5. Lupia T, Scabini S, Mornese Pinna S, Di Perri G, De Rosa FG, Corcione S. 2019 novel coronavirus (2019-nCoV) outbreak: a new challenge. J Glob Antimicrob Resist. 2020 Mar; 21:22-7

6. WHO. The importance of caregiver-child interactions for the survival and healthy development of young children: A review. Geneva: World Health Organization; 2004.

7. Norredam M, Nellums L, Nielsen RS, Byberg S, Petersen JH. Incidence of psychiatric disorders among accompanied and unaccompanied asylum seeking children in Denmark: A nation-wide register-based cohort study. Eur Child Adoles Psy. 2018; 27:439- 46.

8. Wang G, Zhang Y, Zhao J, Zhang J, Jiang F. Mitigate the effects of home confinement on children during the COVID-19 outbreak. Lancet. 2020; 395:945-7.

9. Liu JJ, Bao Y, Huang X, Shi J, Lu L. Mental health considerations for children quarantined because of COVID-19. Lancet. 2020;4: 347-9. https://doi.org/10.1016/S2352-4642(20)30096-1

10. Fegert et al. Child Adolesc Psychiatry Ment Health (2020) 14:20 https://doi.org/10.1186/ s13034-020-00329-3

11. Brough $\mathrm{H}$ et al. Managing childhood allergies and immune deficiencies during respiratory virus epidemics-The 2020 COVID-19 pandemic: A statement from the EAACI-section on pediatrics. Pediatr Allergy Immunol. 2020;00:1-7

12. Oreskovic NM, Kinane TB, Aryee E, Kuhlthau KA, Perrin JM, The Unexpected Risks of COVID-19 on Asthma Control in Children, The Journal of Allergy and Clinical Immunology: In Practice (2020), doi: https://doi.org/10.1016/j. jaip.2020.05.027

13. Togun, T., Kampmann, B., Stoker, N.G. et al. Anticipating the impact of the COVID-19 pandemic on TB patients and TB control programmes. Ann Clin Microbiol Antimicrob 19, 21 (2020). https:// doi.org/10.1186/s12941-020-00363-1
14. Pinar Senkalfa, Burcu et al. "Effect of the COVID-19 pandemic on anxiety among children with cystic fibrosis and their mothers." Pediatric pulmonology, 10.1002/ppul.24900. 12 Jun. 2020, doi:10.1002/ppul.24900

15. Dubey S et al, Psychosocial impact of COVID-19, Diabetes \& Metabolic Syndrome: Clinical Research \& Reviews 14 (2020) 779-788

16. World Health Organization. \#HealthyAtHome-mental Health. Available at: https://www.who.int/campaigns/connecting-the-world-to-combat-coronavirus/healthyathome/healthyathome-mental-health, Accessed July 6, 2020.

17. Origiles M, Morales A, Delvecchio E et al. Immediate psychological effects of the COVID-19 quarantine in youth from Italy and Spain, April 21. http:/dpi.org/10.31234/osf.io/5bpfz. Accessed on: $2 / 4 / 2020$

18. Brooks SK, Webster RK, Smith LE, et al. The psychological impact of quarantine and how to reduce it: rapid review of the evidence. Lancet 2020; published online Feb 19. https://doi. org/10.1016/ S2215-0366(20)30077-8

19. Propeller data shows $14.5 \%$ med adherence lift since COVID-19 outbreak began. Madison, WI: Propeller Health. [Internet]. [cited 2020 April 20]. Available at: https://www.propellerhealth. $\mathrm{com} / \mathrm{press} / \mathrm{clinical}-\mathrm{blog} /$ propeller-data-shows14-5-med adherence-lift-since-covid-19-outbreak-began/

20. Brazendale K, Beets MW, Weaver RG, et al. Understanding differences between summer vs. school obesogenic behaviors of children: the structured days hypothesis. Int J Behav Nutr Phys Act 2017; 14: 100

21. Mi X., Zhiruo Z., Keisuke K. Impact of COVID-19 pandemic on children and adolescents' lifestyle behavior larger than expected, Prog Cardiovasc Dis. 2020 Apr 30 doi: 10.1016/j. pcad.2020.04.013

22. Rundle AG, Park Y, Herbstman JB, Kinsey EW, Wang YC. COVID-19 Related School Closings and Risk of Weight Gain Among Children. Obesity. 2020. doi:10.1002/oby.22813 


\title{
Резиме
}

\section{ПАНДЕМИЈАТА СО COVID-19 И СЕМЕЈСТВАТА НА ДЕЦА СО ХРОНИЧНИ РЕСПИРАТОРНИ ЗАБОЛУВАњА}

\author{
Татјана Зорчец ${ }^{1}$, Татјана Јаќовска², Весна Мицевска ${ }^{1}$, \\ Катерина Бошковска ${ }^{2}$, Валентина Цвејоска Чолаковска ${ }^{1}$ \\ ${ }^{1}$ Универзитетска клиника за детски болести, Скопје, РС Македонија \\ ${ }^{2}$ Институт за белодробни заболувања кај децата, Скопје, РС Македонија
}

Пандемијата со COVID-19 предизвика огромна промена во секојдневното функционирање кај милиони луѓе во светот. Епидемиолошките мерки за спречување на можна инфекција ги зголемија можните ризици за менталното и за физичкото здравје.

Спроведовме истражување за да ги испитаме потребите и предизвиците на семејствата со деца со хронични респираторни заболувања. За оваа намена создадовме прашалник со општи информации за семејството, општи информации за детето со хронично респираторно заболување, целокупното физичко и ментално здравје пред и за време на пандемијата, потребите и состојбата со менталното здравје на родителите/старателите.

Ова истражување покажа дека оваа група на семејства на деца со хронични респираторни заболувања претрпеле значајни финансиски потешкотии и го промениле начинот на кој ги вршат професионалните и едукативните обрасци заради пандемија. Повеќето од децата биле со стабилни во физичкото здравје, но нивното ментално здравје се влошува. Ова веројатно се должи на редовниот контакт со медицинскиот персонал, но не и со професионалците за ментално здравје. Оваа група деца има значително намалување на нивната физичката активност и ги зголемиле часовите поминати пред ТВ-екраните. Понатамошниот ефект врз физичкото и врз менталното здравје треба и понатаму да се истражува.

Клучни зборови: пандемија со COVID-19, хронични респираторни заболувања, деца 